tion' of workers transferred from one area to another where climatic conditions differ. In the Katanga mining district no workers from neighbouring or distant areas may be employed unless they have spent a period in one of these acclimatization camps.

\title{
The War Effort of the Belgian Congo
}

IN a speech made at the opening of the Conseil de Gouvernement in December 1942, and published by the Courier d'Afrique, Léopoldville, Governor-General Ryckmans reviewed the war effort of the Belgian Congo, both military and economic. In the economic sphere they were producing as far as possible what was needed by the Allies, especially tin, cobalt, tungsten, and rubber. He welcomed the presence of American soldiers in the Congo as brothers in arms. 'When they leave,' he said, ' we shall be saying good-bye to our friends.' Speaking of the situation in regard to supplies, he hoped that goods for African consumption would not be severely curtailed, as a shortage of cotton cloth and other goods might cause a general drop in the production of raw materials needed for the war. It had been necessary to make plans for the conscription of Africans for essential work, as a parallel measure to the civil call-up of Europeans. Such conscription of Africans would be strictly supervised, and the same conditions of work and welfare would be demanded of employers as those in force for the military carriers, which were generally considered to be very satisfactory.

\section{Lectureship in Anthropology at Cambridge University}

Wr have been asked to print the following announcement:

The Vice-Chancellor gives notice that the Appointments Committee of the Faculty of Archaeology and Anthropology propose to appoint a University Lecturer in Anthropology. The appointment will be governed by the Statutes and Ordinances of the University. Candidates are requested to address any inquiries, and to send their application with such evidence of their qualifications as they think fit, to the Secretary of the Appointments Committee of the Faculty of Archaeology and Anthropology at the Museum of Archaeology and of Ethnology, Cambridge, on or before is April i944.

\section{CONTRIBUTORS TO THIS NUMBER}

Mr. H. V. Meyerowitz: Supervisor of Arts and Crafts at Achimota College.

Mr. K. C. MurraY: Superintendent of Education in the Southern Provinces of Nigeria; at present working in the Information Office at Lagos; has done considerable research into Nigerian crafts, has trained students as craftsmen and craft teachers, and organized an exhibition of their work in London shortly before the wat.

The Rev. R. W. Stopford: Principal of Achimota College; formerly Principal of Trinity College, Kandy, Ceylon.

Mrs. Theresa Cahan : Administrative Officer, Ministry of Economic Warfare; Secretary to International Economic Policy Study Group, Royal Institute of International Affairs; prepared Report on Colonial Public Finance under the auspices of the National Institute of Economic and Social Research.

Mr. A. PLUTYNSKr : Polish industrialist and writer on economic subjects; author of economic studies in Polish, and of The German Paradox (1933) and We are IIs Millions (not yet published).

Mr. G. D. R. PhIluxps: Author of Dawn in Siberia, The Mongols of Lake Baikal, and Russia, Japan and Mongolia.

Monsieur Th. Monod: Director of the Institut Français d'Afrique Noire. 